\title{
The Impact of the Informal Employment on the Social Security Deficits in Turkey
}

\author{
Adem Yavuz Elveren ${ }^{1,2}$ \\ Received: 20/11/2014; Revised: 14/12/2014; Accepted: 16/12/2014
}

\begin{abstract}
This study examines the impact of the formalization of the labor market on social security deficits in Turkey. After a brief discussion on the causes and consequences of the informality of the economy, the paper reveals the effect of possible developments in the labor market, -such as the reduction in informal employment, the decrease in contribution evasion, and the increase in youth employment and women's employment-- on the deficits, which has increased since the early 1990s. To assess the effect, we utilize a simple actuarial model to project the deficit through 2050 under different scenarios. The results point to the importance of increasing female labor force participation, preventing evasion of social security contributions, and show the effect of an ageing population.
\end{abstract}

Keywords: C15, H55

JEL Codes: Informal sector, social security, Turkey

\footnotetext{
${ }^{1}$ Department of Economics, History and Political Science, Fitchburg State University, Fitchburg, MA 01420, USA

${ }^{2}$ Corresponding Author: email: ademyavuzelveren@gmail.com
} 


\section{Introduction}

Pay-as-you-go systems in many countries have faced with financial crises. Turkey is one of these countries, where the problem is particularly severe. However, unlike the major industrialized countries across the world the deficit of the system in Turkey is not particularly caused by aging population. As a matter of fact the country has the youngest population of EU; and aging population seems to be a problem only starting with the 2030s. The most remarkable problem in the system was extremely low retirement ages, which was addressed by the 1999 reform. However, this parametric change was one part of the problem.

In fact, informal employment is one of the main sources of the social security deficits that have increased since the early 1990s. Informal employment is a standing burden on the Turkish economy. Informal employment is an essential part of the 'informal economy', which is a wider concept (for further discussion on the informal employment and the informal economy, see Yamada, 1996; Bernabe, 2002; Hussmanns, 2004; Perotti and Puerta, 2009). In this study we deal with those who are not registered with the Social Security Institution (SGK) and use the term 'informal employment' to refer this issue.

One out of three workers is employed in the informal sector (Turkstat, 2014). This ratio is extremely high for a healthy economy because too few people finance the current retirees. As a matter of fact, the active/passive ratio was as low as 2.7 in 1999 and even declined further to 1.78 in 2009. In fact, it is possible to increase this ratio as high as to 5 by eliminating the informal sector. Considering this fact, this study argues that extending the coverage of public pension system by registering those who work in the informal sector will relief the financial burden of the system by creating immediate increase in revenues while creating corresponding liabilities to be paid in remote future. That is, reducing the size of the informal sector is one potentially painless means of reducing the deficits of the system. Reducing underreporting of wages and increasing youth and female employment are other policy options in this context.

On the other hand, the Turkish economy has been passing through a remarkable transformation. The shrinking agricultural sector is a key issue in this transformation in the context of (in)formality because informality is commonly found in the agricultural sector than in the non-agricultural one. This is of importance in terms of the reducing the size of the informal employment.

Therefore, this study has a timely objective. It attempts to present general remarks about the informal economy with a special focus on the informal employment, and to show the effect of possible shrinking of the informal sector on the deficits of the social security system in Turkey under various scenarios. The paper compares the effect of reducing the size of the informal employment with other options for improving the financial balance of the Turkish social security system.

To do so, the paper introduces general information of the social security system in Turkey in the next section. Section 3 examines the main aspects of informal employment. Section 4 presents the model. The results of the projections are discussed in section 5. Finally, we summarize the main results of the paper in the conclusion.

\section{The Recent Social Security Reforms in Turkey}

The Turkish social security system is a two-pillar system. The first pillar used to constitute of three main institutions, namely the Social Insurance Institution (SSK), the Retirement Fund (ES), and the Social Security Institution of Craftsmen, Tradesmen and other Self-Employed (Bag-Kur) until they were unified under the Social Security Institution (SGK) in 2006. The 
Individual Pension System (IPS), a privately managed defined contribution scheme, established in 2003 is the second pillar of the social security system ${ }^{3}$. While the first pillar provides a tax-financed minimum pension covering $83 \%$ of the whole population, IPS provides additional retirement income to its about 4.5 million participants. The contribution rate in the public scheme is $20 \%$, where $9 \%$ is paid by the employee and $11 \%$ by the employer. The state also makes payment the scheme through a one fourth total premium paid to the SGK. Currently, the retirement age is 58 for women and 60 for men and will increase gradually for persons entering the work force for the first time to reach 65 years for both genders by 2048 . The system currently has high replacement rates, $75 \%$ for ES, and $65 \%$ for both SSK and Bag-Kur, which will be reduced to $50 \%$ in ten years.

The social security system has presented an increasing deficit since the early 1990s due to some structural problems, such as a lower retirement age, low level setting for insurable earnings, inefficient use of contributions, amnesties on delay penalties for unpaid contributions, an increase in the payment of benefits and particularly health care costs due to higher life expectancy, and an expanding informal sector (Elveren, 2015). Figure 1 shows the trend of social security deficits.

Figure 1: Transfers to Social Security Institutions (SSI) and Active/Passive Ratio

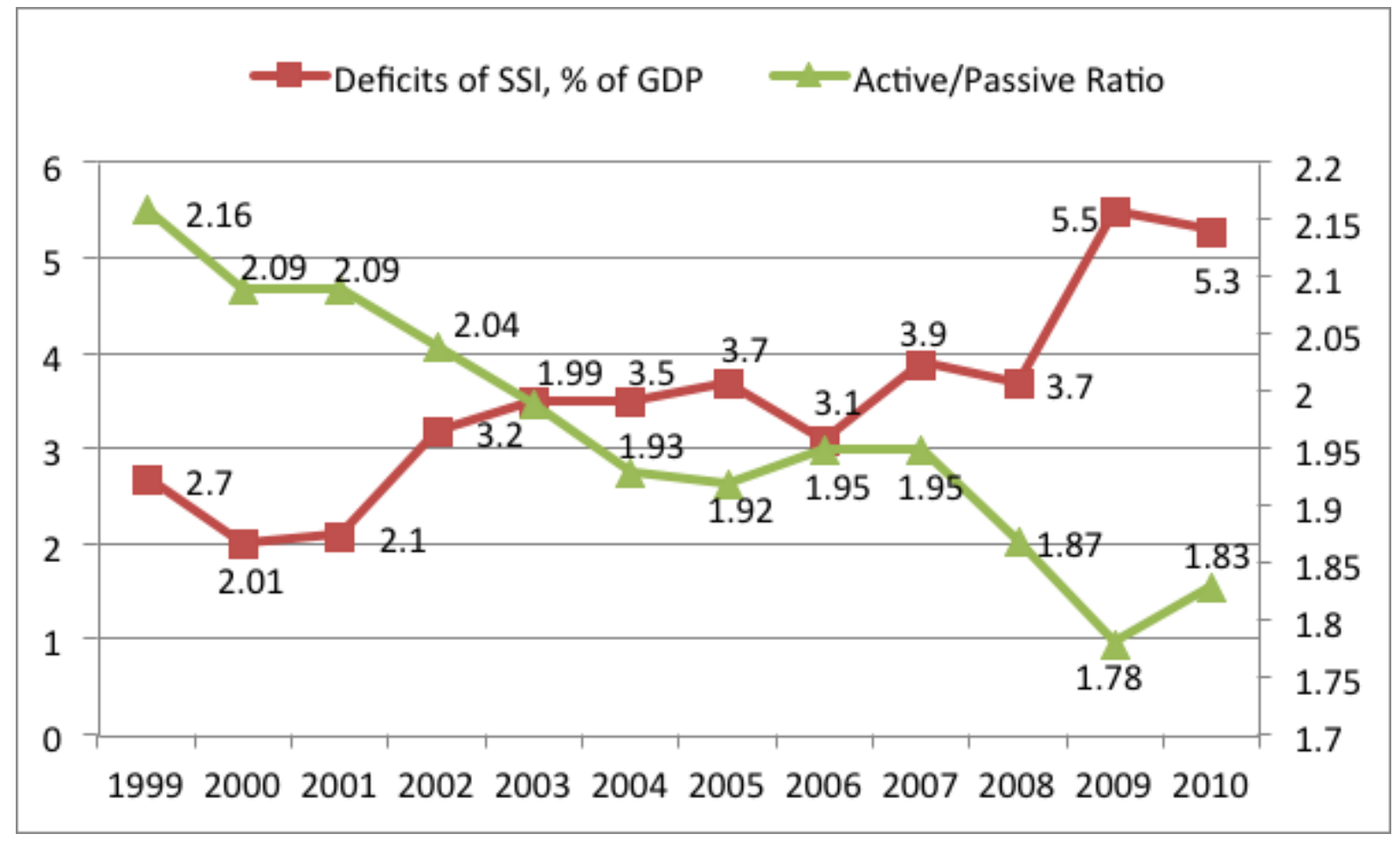

Source: Ministry of Finance and Social Security Institution

Considering the warnings of reports by international institutions on the future of the system, the government realized that comprehensive social security reform was a matter of urgency in order to reduce the pressure of social security institutions on the public deficit. ILO (1995), for example, predicted that the total deficit of the social security system will reach 10.1 percent of GDP in the absence of intervention by the year 2050 (Elveren 2008a).

Two major reforms were implemented. The aim of the first one, the 1999 reform, was to set up a series of administrative reforms to rein in the deficit of Turkey's three state social

\footnotetext{
${ }^{3}$ See Elveren and Hsu (2007), Bozkuş and Elveren (2008), Elveren (2008a; 2008b), Şahin et al. (2010), Şahin and Elveren (2011), and Şahin and Elveren (2014) for further discussion on different aspects of the system.
} 
security funds. The main implementations to reach these goals were to extend the average contribution period and shorten the benefit collection period by increasing the minimum entitlement age. The low retirement ages (i.e. 38 for women and 43 for men) were increased as mentioned before. Also the number of contributory days was increased from 7000 to 9000 initially but then decreased to 7200 for new contributors. It has remained at 9000 for self employed workers and civil servants.

The second reform was launched in 2006. The reform had four main aims. The first was to launch the General Health Insurance (GSS) system, which aims to cover every citizen by providing basic health services. The second was to consolidate the dispersed social benefits that have been provided by several institutions (i.e. SSK, ES, Bag-Kur) with respect to different criteria. The third aim was to establish a new retirement insurance program. Finally, the last was to set up a new institutional structure which will integrate current institutions under a single roof (SGK, 2004). With this reform, contribution and benefit conditions of the three institutions were equalized. That is, the hierarchy and discrepancy in terms of benefits between workers, civil servants and self-employed were eliminated.

These major reforms in the social security system have addressed the structural problem of the system partially. While early retirement age rules have been changed, the issue of a sizable informal sector as a major cause for deficits has not been addressed properly. There were some attempts to combat against informal employment. For example, increasing the number of inspectors, strengthening the coordination between institutions, and introducing administrative fines were some of these implementations. However, the large deficits of the system remain and are expected to grow. Since it is not preferable to increase contribution rates and/or retrench the benefits the options examined in this paper is of importance. Below we attempt to sketch a general picture of the informality of the economy, a major issue in the social security system in Turkey, and show its effect on the deficits of the social security system.

\section{Informal Employment in Turkey}

There has been a significant rise in attention to the informal sector by trade unions, NGOs, as well as the government in Turkey (DPT, 2001; KADIM, 2010; Oviedo, 2008; TISK, 2003; Ülgen and Öztürk, 2006 among many others). The literature on the informal economy in Turkey shows that the size of the informal economy changes substantially according to the chosen period, especially due to the method adopted (Bulutay and Taşc1, 2004; Kan and Tansel, 2014; and see Elveren, 2010b for a brief review). Overall, the size of informal economy is more than $50 \%$ of GNP (KADIM, 2010), and every one out of three people works in the informal sector. Informality in Turkey is comparable to other upper-middle income countries (Oviedo, 2008). That is, it is not evident that Turkey suffers from a higher than expected level of informality, given its income level.

There are various causes of the informality: production structure, productivity, scale of firms, demographic trend, migration, urbanization, globalization, increasing competition, taxing policy, employment policy, bureaucracy, and some socio- psychological and ethical reasons.

An essential part of informality is associated with the rational choices of firms and workers to remain informal due to advantageous costs and benefits (Maloney, 2004). This is of great importance when one deals with 'formalization' of the labor market. That is, a policy that does not take this fact into account cannot succeed, even may lead to more detrimental consequences. In fact, the informal sector is a shelter for many low skilled low educated workers particularly during periods of recessions. 
Bureaucracy with intense regulations, such as high entry costs, strict labor regulations, long and complicated procedures, substantially discourage the movement toward formality. For example, a total of 193 official documents in total is required in order to open a factory (KADİM, 2010).

Low quality of and trust in institutions due to corruption, weak rule of law, lack of accountability, low monitoring and enforcement and weak coordination between public institutions appears as other shortcomings in this context. Moreover, low quality of social protections can lead to higher informality as well. Employees prefer making agreement with the employer and stay informal if they are not satisfied with the services. In this context, flexicurity has come out as a crucial concept. That is, encouraging flexibility in business organizations should go hand in hand with rearrangement of the social security system for flexible workers. In line with the European Council directives to encourage flexibility in the labor market, Turkey provided flexibility to temporary employment with the new labor law (i.e. No. 4857). However, it is argued that this law mainly addresses short term flexibility, not a fundamental restructuring and it does not involve social dialogue and employee participation in contrast to the suggestions of the EU directives ${ }^{4}$ (Taymaz and Özler, 2005).

The structure of the social security system should improve to cover the widest range of formal jobs. Otherwise, workers will have a tendency to remain informally employed, particularly if those formal jobs have less flexibility and more taxation (Maloney, 2004). It is also important that universal social protection policies have to be carefully designed to avoid discouraging participation in the formal sector (ibid. pp. 1173). For example, the contributory days threshold is too high for part-time workers and this makes them either excluded from the system or have a very low pension if they are able to meet with minimum days requirement (Karadeniz, 2009).

Due to the increasing competition as a result of integration into global markets particularly European- small and medium sized enterprises (SMEs) have a tendency to remain informal in order to sustain their cost advantages. Lower productivity in SMEs, which consists of almost $99 \%$ of all enterprises but involve only $46 \%$ of total employment in the economy, is a key factor that adds to the informality. Lower productivity in SMEs and higher informality go hand in hand (Taymaz, 2009).

Lack of access to land, credit and subsidies appears as one of the major reasons of informality and source of productivity difference between informal and formal sectors (Perry et. al. 2007; Straub, 2005). Informal firms usually involve five or fewer employees and often operate from the household, involving low human capital. More importantly, these firms have little, if at all, intention for growth and have a shortage of capital (i.e. difficulty to access the credits).

Since 2001 the Turkish Economy has experienced an unprecedented transformation process towards an industrialized economy. The development indicates that there has been a remarkable decline in the number of people who work in the informal sector, which is particularly of importance for the future of the social security system. The ratio of informal employment dropped from $52.9 \%$ in 2001 to $43.8 \%$ in 2009 ; the figures for the same years

\footnotetext{
${ }^{4}$ High severance pay is a crucial factor that reduces the flexibility of the labor market. Therefore employers prefer making existing employees work longer rather than hire more workers (Taymaz and Özler, 2005; Ülgen and Öztürk, 2006). The new labor law is to change this provision. Indeed, while average weekly working hours have been declining in Europe to an average of 38.5 hours for EU-15, Turkey ranks first with 52 hours among OECD countries in 2004 (World Bank, 2006).
} 
considering informal employment out of total non-agricultural employment, on the other hand, increased from $29.5 \%$ to $30.1 \%$ (Turkstat, 2014). The main factor behind this trend is a declining share of agricultural employment in total employment. That is, since informality is inherently in the agricultural employment, when it shrinks in general, the share of total informal employment in the total employment declines.

While the ratio of the increase in insured workers to the increase in total employment is 2.94 between 2002 and 2007, it was as low as 0.54 for the previous decade (Pamuk and Teksöz, 2008). In other words, between 1993 and 1998, for every two new workers, only one enrolled in social security system, while in the other period, for every one new worker three enrolled in social security system, meaning that there is a remarkable shift of workers from the informal to the formal sector. This significant increase is due to the change in the agricultural subsidy program in 1999. Since then there has been a steady and rapid decline in agricultural employment. Compared to the last decade there has been a $30 \%$ decrease in the size of agricultural employment. This rapid transformation has brought its own challenges and opportunities (Sak, 2008). Informal employment is declining because the labor force moves from the agricultural sector, where the informality is around $85 \%$, to other sectors -mainly the service-, where informality is around $30 \%$.

However, the migration from rural to urban areas creates some problems. Indeed, informal employment has increased in industry from $26 \%$ in 2001 to $31 \%$ in 2006 (Turkstat, 2014). Although there is an increase in overall productivity in Turkey, those coming from agricultural sectors present a lack of skills and the pull down the average productivity in the economy.

There is a strong linkage between informal employment and social security deficits. Due to the sizeable informal economy, a smaller amount of premium is collected by social security institutions, which in turn leads to deficits in the system. Since government finances this deficit through direct transfers from the central budget, fewer funds are left for social aids for the poorer strata of the society. That is, the existence of an informal sector impacts the poor and deteriorates the income inequality. In addition, higher budget deficits worsen income distribution via channel of higher interest rates. As people become poorer they are more likely to become involved in the informal sector. In fact, compared with other upper-middle income countries, Turkey has one of the worst income distributions, and inequality has increased since the early 1980s, particularly in the 1990s (Elveren and Galbraith, 2009; Elveren, 2010a).

High taxes appear as one of the most crucial factors behind higher informality (Schneider and Enste, 2000; Önder, 2001). These two issues feed each other. While higher taxes create a tendency to increase informal economy, extending informal economy eventually reduces total tax revenue by shrinking the tax base, which in turn creates a need for higher tax rates. Distribution of the tax burden, taxing justice and perceptions of tax payers on government expenditures affect the size of informal economy. Those for whom tax exemptions do not apply are the ones who are more likely to operate informally.

What is critical in the context of tax collection is that while better regulation enforcement may bring marginally higher revenues, ensuring full compliance does not pay off in terms of costs and benefits. Indeed, increased enforcement alone to increase revenue may end up with reduced output as observed in Argentina and Brazil due to the costs of enforcement and negative effects on the informal businesses (Ronconi, 2007; Oviedo, 2008). This emphasizes the importance of the pace of transition from informality into formality and points to the fact that policies targeting the unregistered economy should complement, or even be preferable to, increased enforcement. Because informality has a complicated structure, one type of policy 
cannot work for all aspects of informality. Therefore, a policy to combat informality should be based on the 'rule of carrots and sticks.'

To sum up, beside some parametric reforms that address the growing deficits of the system, the paper argues that reducing the size of informal employment and underreporting wages is an attractive policy option. Bringing unregistered workers into the system is a painless way of improving the system's finances by spreading the financial burden of the system on to more people.

\section{Model and Assumptions}

We develop a simple actuarial model based on Sayan (1999), in which the revenue and payments of the social security system are simulated with respect to different assumptions on employment level, wage increase and size of the informal employment. In basic sense, there are two distinctions between our model and the one in Sayan (1999). First, we consider both genders with different wage levels and life expectancies. Second, we incorporate both disability and death payments as well as some other minor payments and revenues. The paper contributes to the literature ${ }^{5}$ by examining the effect of a shrinking of the informal sector on the deficits of the social security system in Turkey. It reveals the effect of important aspects of the Turkish economy such as women's employment, youth employment, and contribution evasion separately.

The model allows us to see the pattern of social security deficits, D, depending on the main actuarial and macroeconomic variables from 2008 until 2050.

$$
\begin{aligned}
D=\sum_{t=2008}^{2050} \frac{1}{(1+\delta)^{T}}[I R & \left.R\left(\sum_{s=M R A}^{L E} A W_{j}^{*} A G W_{j}\right)+\left(\sum_{y=25}^{L E} A W_{j} * \operatorname{Pr}(\text { dis })\right) * A G W_{j}\right) \\
& +\left(\sum_{y=25}^{M R A} A W_{j} * \operatorname{Pr}(\text { death })\right) * A G W_{j} \\
& \left.+O P-C R\left(\sum_{z=\min W A}^{\max W A} A W_{j}^{*} A G W_{j}\right)-O R\right]
\end{aligned}
$$

where,

$T=\mathrm{t}-2008$ and $\mathrm{t}=2008, \ldots, 2050$

$D$ : Deficit, the revenue-payment difference in the social security system

IRR: Income Replacement Rate

$\operatorname{Pr}($ death $), \operatorname{Pr}($ dis $)$ : Probabilities of the occurrence of death and disability, respectively

$C R$ : Contribution Rate

$A W:$ Number of Active Workers

$A G W$ : Average Gross Wage

$O P$ : Other Payments

OR: Other Revenues

$L E$ : Life Expectancy

MRA: Minimum Retirement Age

$\min W A$ : Minimum Working Age

\footnotetext{
${ }^{5}$ In a relevant study, Değer (2011) utilizes a 30-period overlapping generations (OLG) model to examine the effects of the parametric changes brought about by the reform from 1999 to 2008, through a replacement rate shock. The study contends that the reductions in the replacement rates would raise saving and therefore capital stock, yielding expansionary effects on the Turkish economy.
} 
$\max W A$ : Maximum Working Age

$\delta$ : discount rate, $4 \%$

$y$ : age index starting from 25 (minimum qualifying age for death and disability payments) to minimum retirement age or life expectancy

$s$ : age index starting from minimum retirement age to life expectancy

$z$ : age index starting from minimum working age to maximum working age

$j$ : index for gender

In this study, we exclude health expenditures and some minor lump sum payments in line with other major projections. Since health services are provided for the whole population, regardless of a person's employment status, and particularly with the recent introduction of the General Health Insurance, it is not possible to project the health expenditures based on the previous data in this actuarial model. We cover the disability insurance and survivor's pension in order to provide a more accurate size of deficits.

In some cases in which there is no definite data for all age ranges, we use the average values. The model treated all variables but the number of active workers (i.e. AW) and average gross wage (i.e. AGW) exogenous. We mainly attempt to capture the effect of changes in the labor market by considering different values (i.e. different increase rates) of AW and AGW. The projected numbers of the insured are based on the 2008 data provided by SGK and the population projection by the OECD. The projected wages are calculated with respect to the 2006 Results of Structures of Earnings Survey conducted by the Turkstat (Turkstat, 2008). All calculations are given in real terms, based on 2008 prices. We take the government inflation projections to get the discount rate of $4 \%$. We assume that wages increase to $30 \%$ of the average real return of a portfolio dominated with government bonds throughout the projection period, in line with the major projections of the Adendum Actuarial Consultancy. Also, wage promotion in a year is taken, 0.005 for women and 0.01 for men, to catch a more realistic picture of the labor market in which there are differences between genders (Elveren, 2008b). Since there is no data on wage promotion, these random ratios taken here only aim to provide a general picture of gender gap in wage promotions. Due to a lack of data in Turkey, we calculate the average working years for different age groups by considering the major samples of working patterns and its applications for other countries.

Since it is not a key point in our analysis, we did not distinguish between employer and employee share of social security contribution, but we take contribution rate, CR, as single rate of 0.23 for old age pension. For simplicity, we ignore the number of contributory days, which can change the income replacement rate, IRR, rather we use $65 \%$ as a single average rate for first 10 years then reduced it to $50 \%$ in line with the government's reform's proposal. The 1980 US CSO Female and Male mortality tables are used to determine life expectancies. We use the retirement age of 65 for both genders but take into account the gradual transition in retirement age in our model. A single probability for disability insurance is used for both genders. The ratios for age ranges are taken from Winklevoss (1993).

Although, the model allows us to investigate the effects of the key parameters as well, such as different replacement rates and contribution rates, we focus on the changes in the labor market, particularly the size of the informal employment.

We assume the following main cases and repeat the simulations for sensitivity analysis.

Base Case: This is the basic scenario based on above assumptions to be compared and contrasted with other scenarios.

Case 1: Reducing Informal Employment: In this case we increased the number of insured for $1.5 \%$ for the first 20 years and $0.5 \%$ for the rest of the period. That is, we increase it by $1.5 \%$ 
at the start of the period and keep it 1.5\% higher than the base year throughout the period, and after 20 years we increase $0.5 \%$ for each year until the end of the period. By doing so, while keeping the population constant, we will see the effect of a very moderate decline in informal employment on the deficit.

Alternative 1: Increases $2 \%$ for first 20 years then $0.5 \%$

Alternative 2: Increases 2\% for first 20 years then $1 \%$

Alternative 3: Increase 2\% for the entire period

Alternative 4: Increase 3\% for entire period

Case 2: Reducing Contribution Evasion: It is a fact that evasion of social security contributions is another crucial factor in the creation of deficits. Employers declare a lower wage than the real level in order to cut the social security contributions. It is stated that the average contribution evasion in Turkey is about $20 \%$ of the actual revenue, according to even the most conservative estimations (Sayan, 1999). Considering this issue, we increase the general wage level of insured people, with no increase in the number of workers. We believe this assumption partially addresses the problem of evasion of the contributions. We assume that wage promotions are doubled and that there is a $10 \%$ increase in overall wage levels.

Alternative 1: 15\% increase in wage levels

Alternative 2: 20\% increase in wage levels

Case 3: Increase in Youth Employment: In this scenario, we aim to examine the effect of possible decline in unemployment among youth. The number of insured aged 10-29 increases $1.5 \%$ for first 20 years and $0.5 \%$ for the rest of the period.

Alternative 1: Increases 2\% for first 20 years then $0.5 \%$

Alternative 2: Increases 2\% for first 20 years then $1 \%$

Alternative 3: Increase 2\% for the entire period

Alternative 4: Increase 3\% for entire period

Case 4: Increase in Women's Employment: This case aims to analyze the impact of an increase in women's labor force participation. This can be considered as a decline in informal women's employment as well. The number of women insured increases $1.5 \%$ for first 20 years and $0.5 \%$ for the rest of the period.

Alternative 1: Increases $2 \%$ for first 20 years then $0.5 \%$

Alternative 2 : Increases $2 \%$ for first 20 years then $1 \%$

Alternative 3: Increase 2\% for the entire period

Alternative 4: Increase 3\% for entire period

Case 5: Full Formalization: Finally we try to see the combined impact of reducing the informal economy and evasion of contributions by assuming the conditions of Case 1 and Case 2 together.

Alternative 1: Combining alternative 1 of Case 1 and alternative 1 of Case 2

Constructing the assumptions in this way allows one to compare sub-cases with each other as well which has the same assumptions in so-called alternatives. Next, the results of the projections are provided and discussed. 


\section{Projection Results and Discussion}

Figure 2 shows social security deficits for the basic scenarios in comparison with the base case until 2050. We prefer presenting the deficits of the base case as the 100 line and show the effect of basic scenarios on the deficits as difference, rather than showing the absolute values of the deficits. This makes it easier to see the impact of the changes in the assumptions. The figure shows that $1.5 \%$ increase in women's employment level for first 20 years and $0.5 \%$ for the rest of the period will create about $2 \%$ less deficits compared with the base case. Considering the small share of women's employment, this is not an unexpected result. However, on the other hand this points out the future benefits of increasing the female labor force in the long run, particularly considering the higher level of women in informal employment.

\section{Figure 2: Impact of Basic Scenarios on Social Security Deficits}

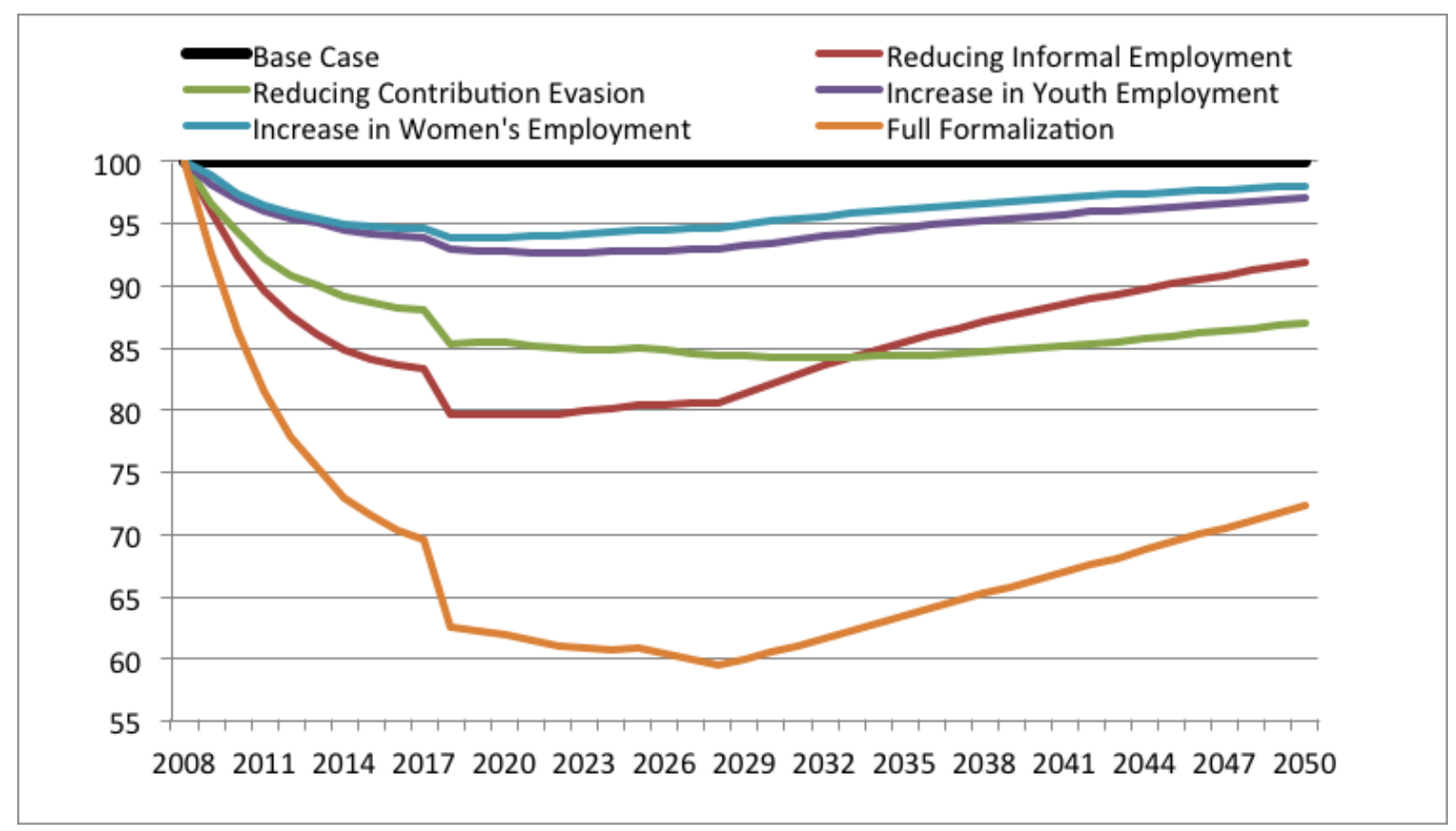

Source: Author's own calculation

There is a slight difference between an increase in women's employment and an increase in youth employment. This simply means that the size of total population of youth (i.e. 10-29) is close to the total number of women workers. An increase in youth employment leads to an additional $1 \%$ (i.e. $3 \%$ ) decline in the deficits than that of women's employment, compared to the base case.

The shrinking informal employment, on the other hand, reduces the deficits about $8 \%$. Although, this remarkable rise in the curve (i.e. decrease of the reduction in the deficits) is mainly due to our assumption where we assume the speed of formalization will decline in the second half of the study period. One can still see the effect of ageing in sensitivity analyses, where we assumed the same formalization trend throughout the period.

Another crucial scenario, reducing contribution evasion, presents a significant decline in deficits, $13 \%$ compared to the base case. This is of great importance in the context of informality, where policy makers usually give more attention to informal employment than to the investigation of the real wage declaration.

Finally, the combination of reducing informal employment and contribution evasion is shown with full formalization, which naturally has the biggest impact on the deficits $(28 \%$ 
compared to the base case). We call it full formalization to emphasize the importance of contribution evasion.

The impact of the ageing population becomes remarkable in the late 2020s. This can be observed from the general shape of all the curves, where they rise (i.e. deficits raise) in the second half of the study period. Also, the figure shows that the reduction of the replacement rate in 2018 reduces the deficits 1-7\% more with respect to the cases compared to the base case. One can note this impact in other figures as well.

Figure 3 shows the sensitivity analysis of reducing informal employment. This allows us to see the impact of various declines in informal employment on the deficits. While very modest increases in reducing informality in the first two alternatives reveal closer results to the base scenario, a rise of $2 \%$ and $3 \%$ in registered employment through the entire period (i.e. alternative 3 and 4 , respectively) cut the deficits $20.5 \%$ and $38.5 \%$, respectively. The difference between alternatives 1, 2 and 3 become visible after 2028 due to our assumptions. Here, it is worth noting that the age composition of unregistered (i.e. informal) workers who would join to the formal sector is of importance. There is no data that allow us to compute the effect of this issue in a more developed model. However, it would not be wrong to argue that those who work in informal sector are mostly younger; therefore, as informal sector gets shrink those who switched to the formal sector will contribute to the system for fairly long time before they are being paid retirement income. Due to this aspect of the formalization that is not captured in our model we can argue that our results would underestimate the improvement that comes with the formalization.

Figure 3: Sensitivity Analysis for Impact of Reducing Informal Employment

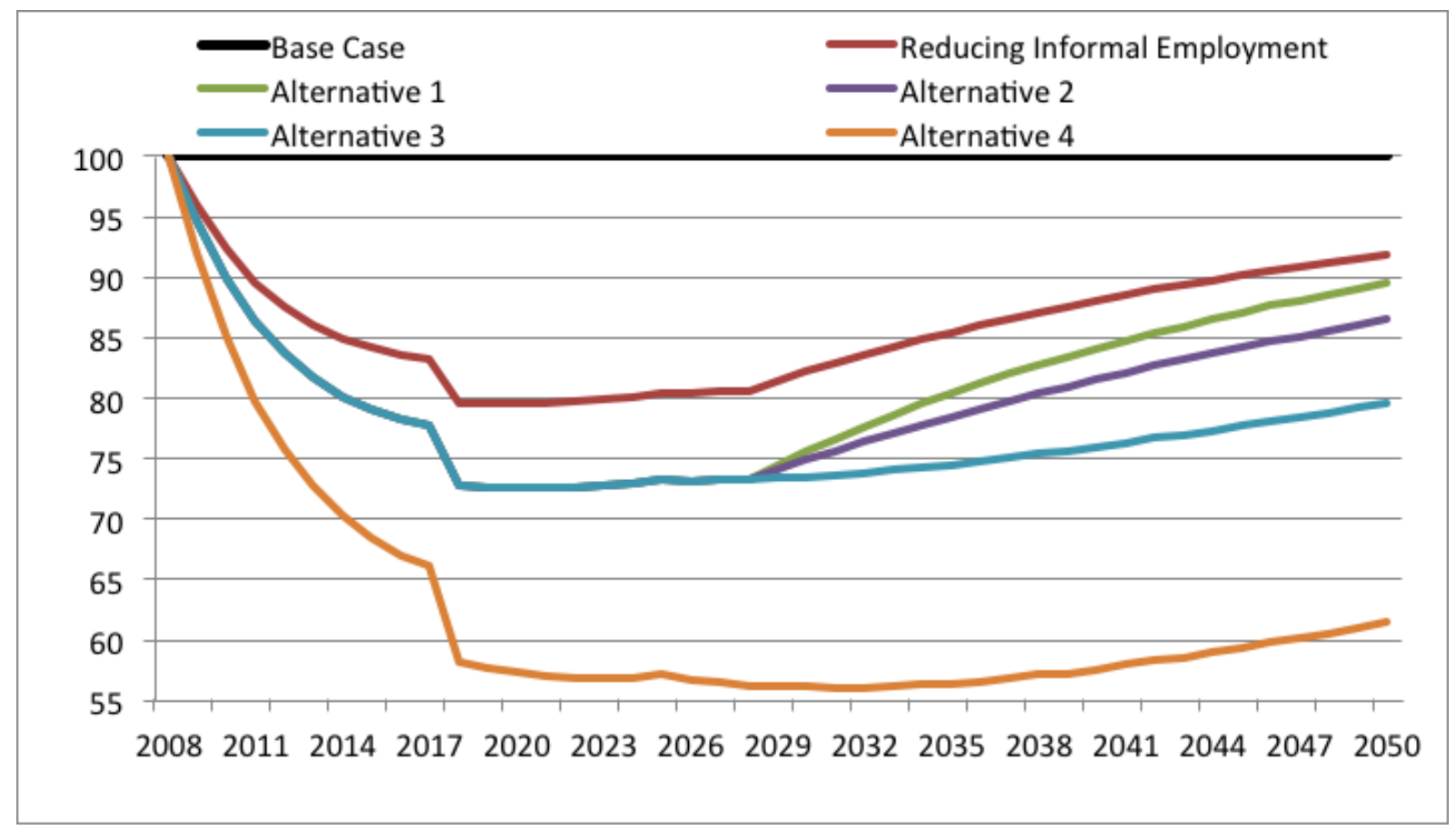

Source: Author's own calculation

Figure 4 shows two more alternative assumptions of reducing contribution evasion. In alternatives 1 and 2 it is assumed that there is a $15 \%$ and $20 \%$ increase in declared wage levels, respectively, rather than a $10 \%$ increase as in the basic case. That is, a $5 \%$ increase in wage levels in each case leads to a $2 \%$ decline in deficits that occurred in the base case. Obviously, the effect of the ageing population is limited in this case. 
Figure 4: Sensitivity Analysis for Impact of Reducing Contribution Evasion

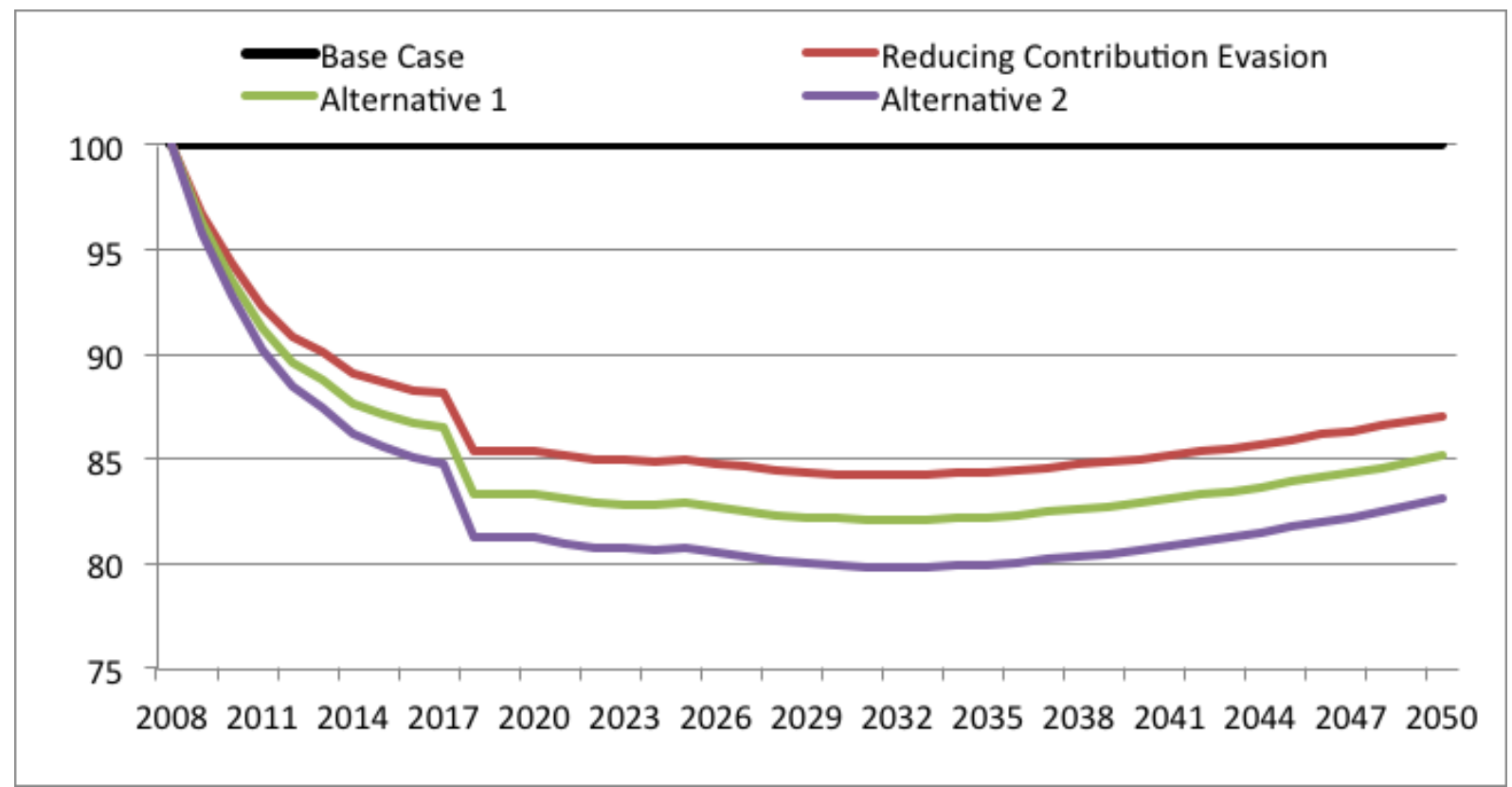

Source: Author's own calculation

The impact of an increase in youth employment under different assumptions is shown in Figure 5. Moving from alternative 3 to alternative 4, an additional $1 \%$ increase in youth employment over the study period leads to an additional $7 \%$ decline in the deficits. It is worth noting that the impact of the ageing population becomes remarkable only in the late 2030s in this scenario, which is certainly a good indicator of the young population that Turkey has. That is, increasing the youth employment will have a significant effect on the long term sustainability of the social security system.

Figure 5: Sensitivity Analysis for Impact of Increase in Youth Employment

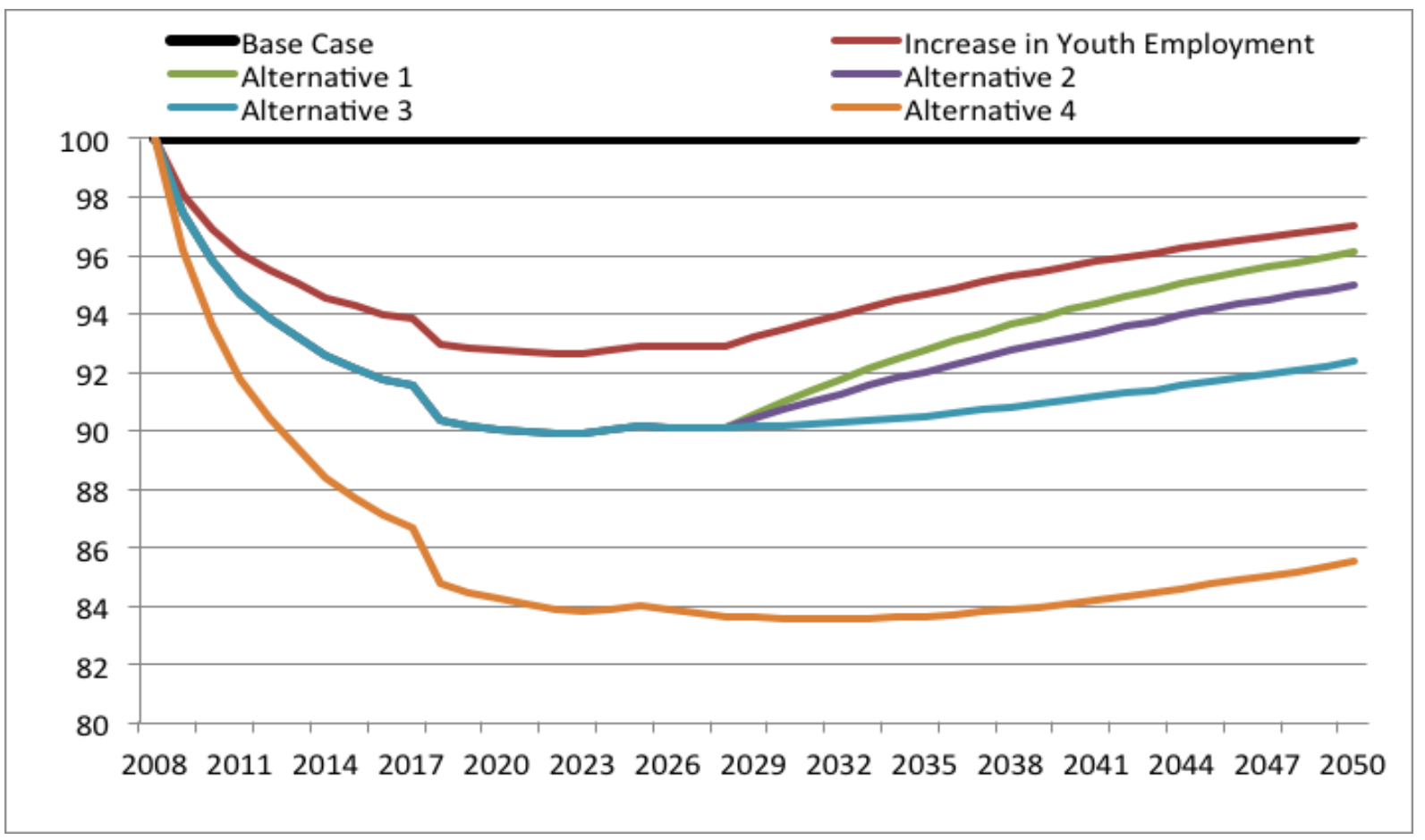

Source: Author's own calculation 
Figure 6 shows the results of sensitivity analysis for the case of increasing the employment of women. Comparing alternative 3 and 4, one can conclude that an additional 1\% increase in the employment of women leads to an additional $4 \%$ decline in deficits compared to the base case. However, as mentioned before, it should be noted that the relative impact of improvement in women's employment on the deficit is not very significant.

Figure 6: Sensitivity Analysis for Impact of Increase in Women's Employment

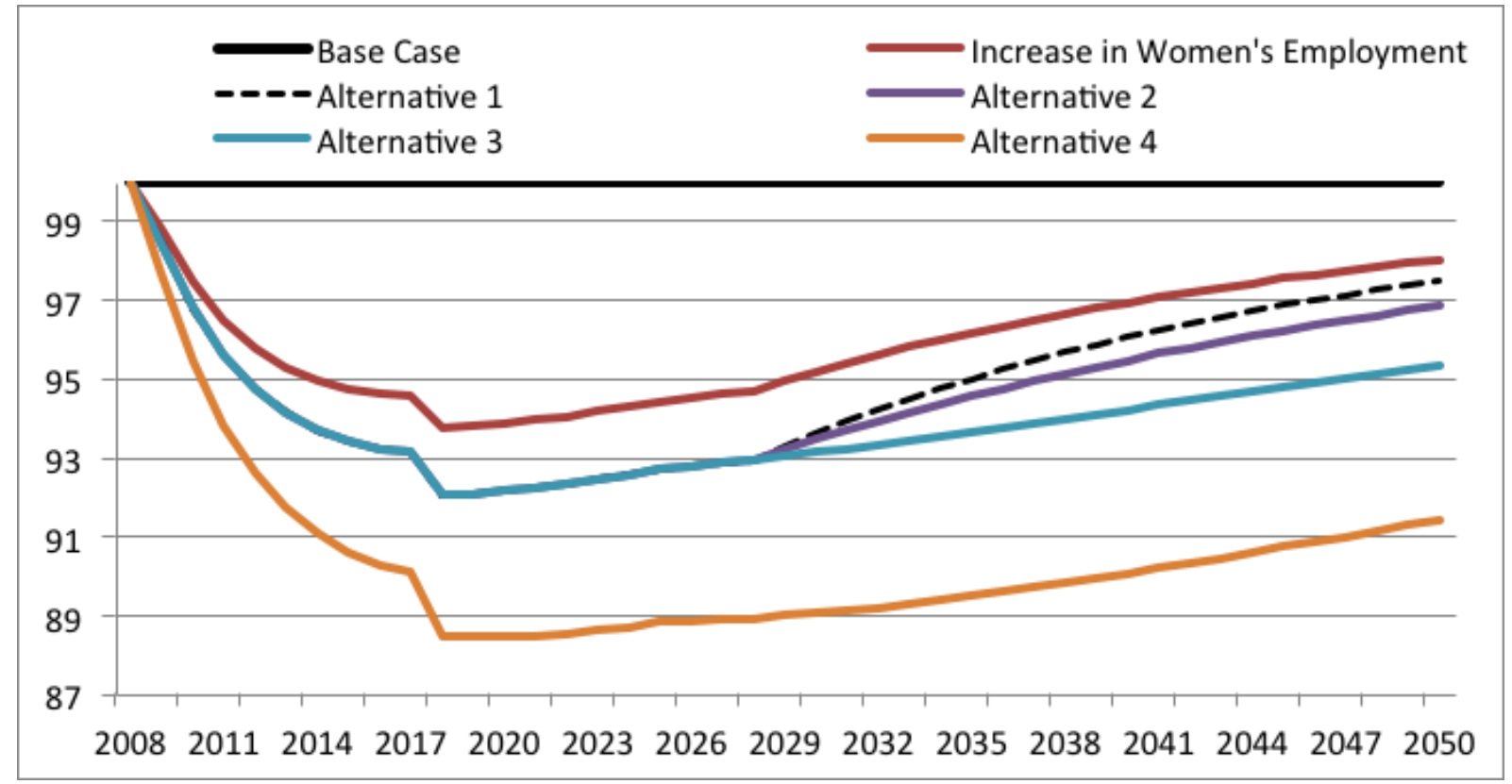

Source: Author's own calculation

The sensitivity analysis of full formalization and their comparison with corresponding basic cases and alternatives are provided in Figure 7. The figure shows that while full formalization leads to $28 \%$ less deficits and its alternative version leads to as high as to $35.5 \%$ compared to the base case.

\section{Figure 7: Impact of Full Formalization comparison with related cases}

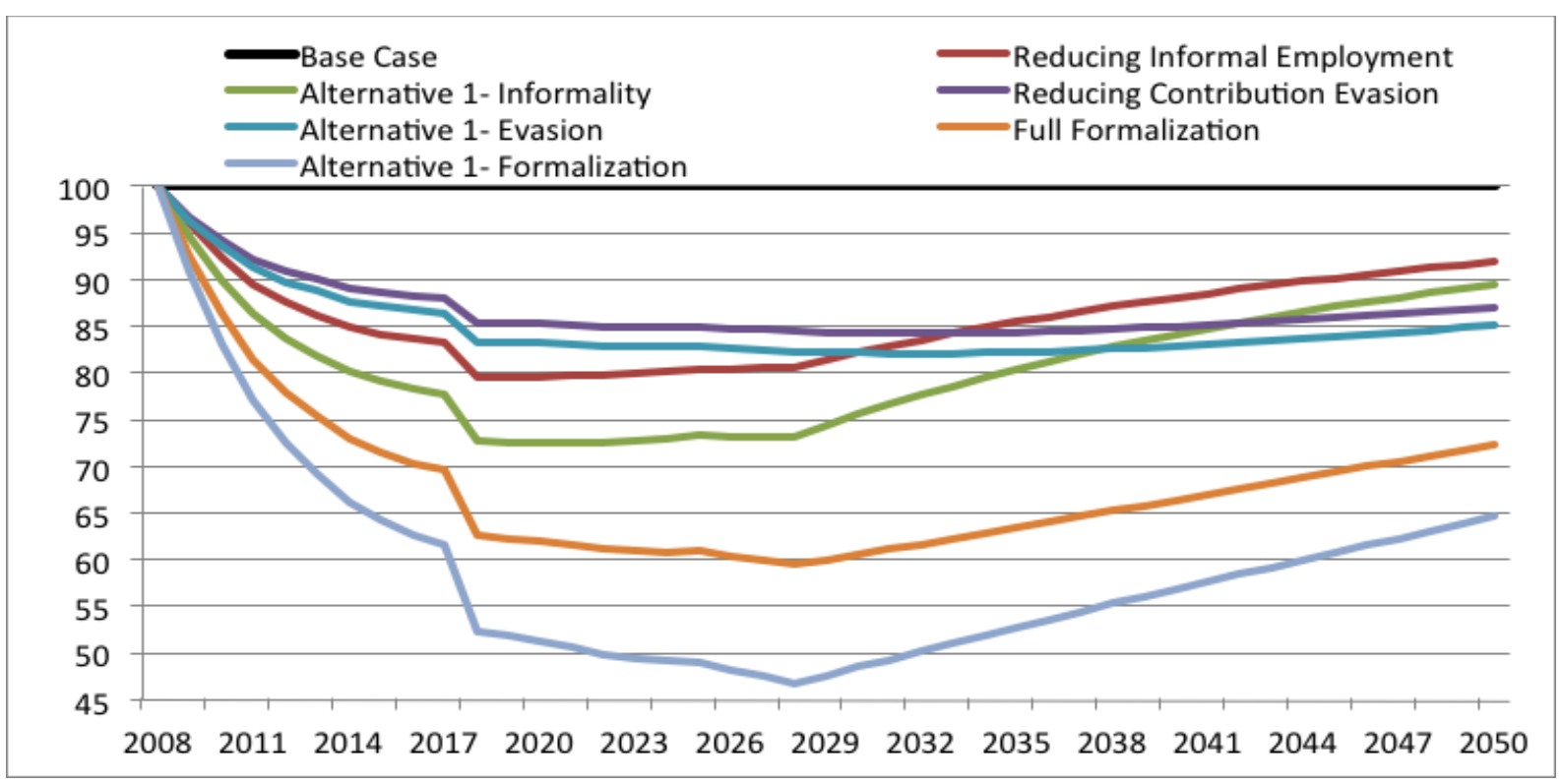

Source: Author's own calculation 


\section{Conclusion}

The main linkage between the informal sector and social security deficits is that low tax collections cause higher tax ratios in order to increase revenue, which in turn feeds informality more. The deficits of the social security system in Turkey, which has been increasing since the early $1990 \mathrm{~s}$, have reached to $5.3 \%$ of GDP in 2010 . Considering large share of informal sector in total employment, alarmingly low women's labor force participation (i.e. 30.8 in 2013), high unemployment rates for women and youth, and higher share of women in the informal sector shrinking the informal sector and tax evasion as well as increasing women and youth employment seem alternative -perhaps better-- options to reduce the deficits compared to increasing contributions rates and reducing pension benefits.

Based on this statement we projected the social security deficits for different scenarios of (in)formal employment in a simple actuarial model. This paper aims to show the effect of an increase in youth employment and women's employment, reduction in contribution evasion, reduction in informal employment, and the last two factors together.

Since the results in this type of study highly depend on the assumptions made, we provided sensitivity analysis for each case. Another shortcoming of this study is validity of the absolute values obtained. To address this, we present the values as a ratio of the base scenario. We acknowledge possible further weaknesses caused by the lack of more accurate data; however, we believe that this does not prevent this study from reaching its modest goal, to sketch a general picture of informality in Turkey.

Our results reveal three more basic facts, in addition to the impact of formalization on the size of social security deficits. First, it shows a relatively minor effect of women's employment and thereby points to the importance of increasing women's labor force participation. Our projections shows that $1.5 \%$ increase in women's employment level for first 20 years and $0.5 \%$ for the rest of the period will create about $2 \%$ less deficits, and an additional $1 \%$ increase leads to an additional $4 \%$ decline in deficits compared to the base case. Increase in youth employment presents very similar results to increase in women's employment. Second, it shows that not just incorporating those unregistered workers but also preventing evasion of social security contributions is a crucial aspect of the big picture of informality. While the shrinking informal employment reduces the deficits about $8 \%$, reducing contribution evasion leads a larger decline in deficits, 13\% compared to the base case. Naturally, in case of the full formalization (i.e. reduction of informal sector and contribution evasion at the same time) the impact is much larger, about $28 \%$ less deficits compared to the base case. Thirdly, our projections show that even under the more optimistic scenarios the deficits began to rise significantly in the late 2030 s due to an ageing population. 


\section{References}

Bernabe, S. (2002) Informal Employment in Countries in Transition: A conceptual framework, CASE Paper No: 56, London School of Economics.

Bozkuş, C. and Elveren, A. Y. (2008) An Analysis of Gender Gaps in the Private Pension Scheme in Turkey, Ekonomik Yaklaşım, 19 (69): 89-106. doi:10.5455/ey.10677

Bulutay, T. and Taşçı, E. (2004) Informal Sector in the Turkish Labour Market, Turkish Economic Association, Discussion Paper 2004/22.

Değer, Ç. (2011) Pension Reform in an Overlapping Model with Multiple Social Security Systems, Ege Academic Review, 11 (4): 563-72.

DPT (The State Planning Organization) (2001) Kayıtdışı Ekonomi Özel İhtisas Komisyonu Raporu. www.dpt.gov.tr, last accessed May 12, 2010.

Elveren, A. Y. (2008a) Social Security Reform in Turkey: A Critical Perspective Review of Radical Political Economics, 40(2): 212-232. doi:10.1177/0486613407310561

Elveren, A. Y. (2008b) Assessing Gender Inequality in the Turkish Pension System International Social Security Review, 61(2): 39-58.

Elveren, A. Y. (2010a) Wage Inequality in Turkey: Decomposition by Statistical Regions, 1980-2001 Review of Urban and Regional Development Studies 22(1): 55-72. doi:10.1111/j.1467-940X.2010.00169.x

Elveren, A. Y. (2010b) The formalization of the labour market and social security deficits in Turkey: What should be done?, $6^{\text {th }}$ International Policy and Research Conference on Social Security, the International Social Security Associations, Luxembourg, 29.91.10.2010.

Elveren, A. Y. 2015. "Financing the Welfare State in Turkey", in Financing Welfare State Systems in Asia, edited by Peter Whiteford and Christian Aspalter, Routledge Studies on Social Welfare in Asia, Routledge. (forthcoming)

Elveren, A. Y. and Galbraith, J. K. (2009) Pay Inequality in Turkey in the Neo-Liberal Era 1980-2001, European Journal of Comparative Economics, 6 (2): 177-206.

Elveren, A. Y. and Hsu, S. (2007) Gender Gaps in the Individual Pension System in Turkey, The University of Utah, Department of Economics, Working Paper No. 6.

Hussmanns, R. (2004) Defining and measuring informal employment, Bureau of Statistics, International Labour Office, Geneva.

ILO, International Labor Organization (1995) Turkish government social security and health insurance project. The Undersecratariat of Treasury.

KADİM (2010) Kayıt Dışı İstihdamla Mücadele (KADİM) Projesi (The Project of Fight Against Informal Employment) http://kadim.istanbul.gov.tr/Portals/Kadim/images/ proje.pdf, last accessed May 12, 2010.

Kan, E. O. and Tansel, A. (2014) Defining and Measuring Informality in the Turkish Labor Market, MPRA Paper No. 57739.

Karadeniz, O. (2009) Annual National Report 2009 Pensions, Health and Long-term Care Turkey, ASISP.

Maloney, W. F. (2004) Informality Revisited, World Development, 32(7): 1159-1178. doi:10.1016/j.worlddev.2004.01.008 
OECD. (2009) Economic Outlook 86: Taxing Wages. doi:10.1787/832724381465

OECD. (2014) OECD Website, www.oecd.org

Oviedo, A. M. (2008) Economic Informality: Causes, Costs, and Policies A Literature Survey of International Experience, report prepared for the Turkey Programmatic Growth CEM Economic Informality and Growth.

Önder, İ. (2001) Kayıtdışı Ekonomi ve Vergileme, İ.̈̈. Siyasal Bilgiler Fakültesi Dergisi, No23-24.

Pamuk, H and Teksöz, T. (2008) İşgücü piyasasındaki yapısal dönüşüm ve kayıt içine geçiş süreci TEPAV Değerlendirme Notlar1 2008- 790, www.tepav.org.tr

Perotti, V. and Puerta, M. L. S. (2009) Personal Opinions about the Social Security System and Informal Employment: Evidence from Bulgaria, SP Dicussion Paper No: 0915, The World Bank.

Perry, G. E., Maloney, W. F., Arias, O. S., Fajnzylber, R., Mason, A. D., and SaavedraChanduvi, J. (2007) Informality: Exit and Exclusion, The World Bank, Washington, D.C. doi:10.1596/978-0-8213-7092-6

Ronconi, L. (2007) Enforcement and Compliance with Labor Regulations, Ph.D. Dissertation, UC Berkeley.

Sak, G. (2008) Nasıl oluyor da ekonomimiz kayıt içine giriyor, Referans Gazetesi (Turkish National Daily Newspaper), 12/04/2008.

Sayan, S. (1999) Türkiye'de Yaşlılık (Emeklilik) Sigorta Prim Kaçaklarının Toplumsal ve Bireysel Maliyetleri, ASO Medya, Eylül 1999, 40-54.

Schneider, F. and Enste, D. (2000) Shadow Economies: Size, Causes, and Consequences, Journal of Economic Literature, 38: 77-114. doi:10.1257/jel.38.1.77

Social Security Institution (SGK) (2004) Proposal for Reform in The Social Security System. Draft Text, July 2004.

Straub, S. (2005) Informal Sector: The Credit Market Channel, Journal of Development Economics, 78: 299-321. doi:10.1016/j.jdeveco.2004.09.005

Şahin, Ş. and Elveren, A. Y. (2014) A Minimum Pension Guarantee Application for Turkey: A Gendered Perspective, Journal of Women, Politics \& Policy, 35(3): 242-270. doi:10.1080/1554477X.2014.921542

Şahin, Ş. and Elveren, A. Y. (2011) Assessing a Minimum Pension Guarantee for the voluntary IPS in Turkey International Social Security Review, 64(3): 39-61. doi:10.1111/j.1468-246X.2011.01401.x

Şahin, Ş., Rittersberger-T1lıç, H. and Elveren, A. Y. (2010) The Individual Pension System in Turkey: A Gendered Perspective, Ekonomik Yaklaşım, 21 (77): 115-142. doi:10.5455/ey.20039

Taymaz, E. (2009) Informality and Productivity: Productivity Differentials between Formal and Informal Firms in Turkey, ERC Working Papers in Economics No. 09/01, Middle East Technical University, Ankara.

Taymaz, E. and Özler, Ş. (2005) Labor Market Policies and EU Accession: Problems and Prospects for Turkey, in B. Hoekman and S. Togan (eds.), Turkey: Towards EU Accession, The World Bank and CEPR, pp.223-260. 
TISK (The Turkish Confederation of Employer Associations) (2003) Kayıtdışı İstihdam Yayın No. 233. http://www.tisk.org.tr/yayinlar.asp?sbj=ana\&ana_id=41

Turkstat (The Turkish Statistical Institute), 2014, Household Labor Force Survey (2001, 2006, 2009), available online at www.tuik.gov.tr, accessed on 16/12/2014.

Turkstat (The Turkish Statistical Institute), 2008, Results of Structure of Earnings Survey, online at www.tuik.gov.tr, accessed on 05/05/2009.

Ülgen, S. and Öztürk, U. (2006) Kayıtdışı Ekonomi ve Sürdürülebilir Büyüme: AB Yolunda Değerlendirme ve Çözüm Önerileri, TÜSİAD Report No: 2007-01/428.

Winklevoss, H. E. (1993) Pension Mathematics with Numerical Illustrations, Second Edition, Pension Research Council and University of Pennsylvania Press: Philadelphia.

World Bank. (2006). "Turkey: Country Economic Memorandum - Promoting Sustained Growth and Convergence with the European Union", Report No. 33549-TR, Volume II: Expanded Report.

Yamada, G. (1996) Urban informal employment and self-employment in developing countries: Theory and evidence, Economic Development and Cultural Change, 44: 289-314. doi: $10.1086 / 452214$ 